\title{
From Sob Sister to Society Editor: The Storied Career of Dorothy Ashby Pownall
}

\author{
TRACY LUCHT
}

IN 1966 Dorothy Ashby Pownall (1895-1979) spoke at an awards banquet for the Iowa City chapter of Theta Sigma Phi, the national society for women journalists. "At heart, I shall always be a reporter," she said, "the proverbial old fire horse who leaps with delayed alacrity into action at the smell of smoke." Recalling her years writing feature stories for the Des Moines Capital, Pownall delivered an exuberant endorsement of journalistic adventure, the kind that leaped from the front page and won grudging respect from crusty city editors. Pownall described for the audience her 50-year career with its "many bypaths," including stints as a stunt reporter, sob sister, advice columnist, freelance poet, and small-town society editor. "In those earliest days, girl reporters were something of an oddity," Pownall said, recounting how creativity and good humor had enabled her to patch together a long, distinguished career that had led the Iowa City Press-Citizen to declare, "[If] there is a dean of women journalists in Iowa City at the present time, Dorothy Ashby Pownall must be it." 1

This biographical article examines the professional life and journalism of a versatile and successful woman writer during the first half of the twentieth century. Historians have long cautioned

1. Dorothy Pownall, speech given at Theta Sigma Phi banquet, 4/27/1966, Iowa City, Iowa, box 1, Dorothy Ashby Pownall Papers (hereafter cited as DAP Papers), Iowa Women's Archives (hereafter cited as IWA), University of Iowa Libraries, Iowa City; "She Has 50 Years of Good Writing Behind Her," Iowa City Press Citizen, 4/22/1966, clipping, box 1, DAP Papers.

THE ANNALS OF IOWA 75 (Fall 2016). (c) State Historical Society of Iowa, 2016. 
against generalizing from one person's experience, but a notable career such as Pownall's is worth examining for the insight it provides about the understudied field of women's journalism in the Midwest. Particularly noteworthy are Pownall's professional tactics and journalism from the beginning of her work for the Des Moines Capital in 1917 through her publications in Ladies' Home Journal and the Saturday Evening Post and until her retirement from the Iowa City Press-Citizen in 1955. Pownall's wide-ranging work reveals her methods of exercising agency within a patriarchal field and illustrates why historians must expand what they consider important journalism if they are to make their narratives more inclusive of women. ${ }^{2}$

Even as notable women journalists and the roles they played have made their way into the scholarly literature, journalism history continues to represent mostly a male point of view, told from the perspective of publishers, editors, and male reporters. The stories of exceptional women have been added to the mix, but their experiences remain "stirred, not shaken," treated as an added spice rather than a key ingredient of journalism history. This has led women's historians such as Carolyn Kitch to argue that scholars must go beyond merely documenting the presence of women in journalism to study "how and why women's careers in the media have taken the shape and direction and quality they have." 3

The first half of the twentieth century is a prime period for examining this question. The American public was becoming more accustomed to seeing women's bylines and writing in metropolitan and rural newspapers. ${ }^{4}$ Elizabeth Cochrane ("Nellie Bly")

2. Maurine Beasley, "Recent Directions for the Study of Women's History in American Journalism," Journalism Studies 2 (May 2001), 207-20; Susan Henry, "Changing Media History through Women's History," in Women in Mass Communication: Challenging Gender Values, ed. Pamela J. Creedon (Newbury Park, CA, 1989), 34-57. The evidence for Ashby Pownall's life comes from her personal manuscripts; her newspaper articles for the Des Moines Capital; her freelance magazine articles; her advice columns in the Cedar Rapids Gazette; and the text of interviews and speeches she gave.

3. Barbara Friedman, Carolyn Kitch, Therese Lueck, Amber Roessner, and Betty Winfield, "Stirred, Not Yet Shaken: Integrating Women's History into Media History," American Journalism 26 (Winter 2009), 163.

4. Eileen M. Wirth, From Society Page to Front Page: Nebraska Women in Journalism (Lincoln, NE, 2013), 17-22; Alice Fahs, Out on Assignment: Newspaper Women and the Making of Modern Public Space (Chapel Hill, NC, 2011), 8, 17-23; Jean 
and Winifred Black Bonfils ("Annie Laurie"), among others, had established a model of stunt reporting that was adopted by adventurous young women who did not mind making themselves the focus of their stories. ${ }^{5}$ Rather than hide the fact that these reporters were women, newspapers highlighted their gender, splashing illustrations and the women's bylines next to bold headlines advertising their latest escapades, such as going undercover in an asylum, as Cochrane was famous for doing, or cross-dressing to cover a catastrophic flood in Galveston, Texas, as Bonfils had dared. To publishers, the publicity offered by these stunts was well worth any perceived impropriety because these "girl reporters" raised circulation and created opportunities to sell branded merchandise, such as the "Nellie Bly" board games sold by the New York World during Bly's globe-trotting adventure in 1889-90. ${ }^{6}$

Some of the same women who engaged in stunt reporting also embodied the role of "sob sister," the pejorative term used for women who wrote subjectively about courtroom drama or urban tragedies. The label had been used by a male journalist to express his displeasure with four formidable women writers who used their front-row seats at the sensational murder trial of Harry Thaw in 1907 to provide intimate, dramatic accounts of the event as it unfolded. ${ }^{7}$ Such sensationalism, criticized at the time and since, has been of major interest to women's historians because of the way women's bodies were, paradoxically, a source of both empowerment and exploitation. ${ }^{8}$ These women entered the public realm not only with their writing, but also with their bodies - consciously putting their physical safety and perceived virtue at risk in order to communicate the gritty realities of urban life. By allowing themselves to be a spectacle, these women gained a voice in the public sphere and earned the ability to tell

Marie Lutes, Front Page Girls: Women Journalists in American Culture and Fiction, 1880-1930 (Ithaca, NY, 2006), 1-11; Deborah Chambers, Linda Steiner, and Carole Fleming, Women and Journalism (London and New York, 2004), 16-22.

5. Maurine Beasley and Sheila Gibbons, Taking Their Place: A Documentary History of Women and Journalism, 2nd ed. (State College, PA, 2003), 64-73; Marion Marzolf, Up from the Footnote (New York, 1977), 37.

6. Fahs, Out on Assignment, 42-47.

7. Marzolf, Up from the Footnote, 32-34.

8. Lutes, Front Page Girls, 15-16. 
stories that otherwise might never have been told. Cultural scholar Jean Marie Lutes writes of these women, "It was the newswomen's role as vehicles of publicity, as both objects and agents of the news, that cemented their identity as sob sisters." 9

Dramatic writing allowed some measure of stylistic freedom because women were not expected to contribute-indeed, were considered incapable of producing-serious journalism. Alice Fahs argues that "human interest writing allowed women a new latitude in both subject matter and expression, permitting them to move beyond the maternal and domestic into realms of wit, satire, and sarcasm." 10 Fahs describes how women who desired a life beyond the satellite existence offered by traditional marriage used the changing nature of newspapers at the start of the century to establish a new public presence. Typically beginning with a position on the women's page, these journalists patched together careers that involved space work - feature articles that newspapers bought by the column inch-and multiple outlets, for which the writers adjusted their voice to appeal to different audiences. If a woman was lucky enough to obtain a salaried staff position at a magazine or newspaper, it was not in the area of what was considered hard or serious news. Rather, the position demanded that a woman writer provide explicitly gendered content in the form of articles about the "four Fs" - food, family, fashion, or furnishings - or that she provide the "woman's angle" on topical news of the day. ${ }^{11}$

During the first three decades of the twentieth century most newspaperwomen worked in the women's section or on the society page. Ishbel Ross, author of the first history of women journalists (who aspired to front-page status herself), described the former as "a department which once merited the scorn it received" and the latter as "the opportunity and the bugaboo of women since the idea first was introduced." 12 Subsequent historians, however, have found evidence that women's page editors empowered themselves to use the segregated space as a public

9. Lutes, Front Page Girls, 70.

10. Fahs, Out on Assignment, 99.

11. Beasley and Gibbons, Taking Their Place, 117.

12. Ishbel Ross, Ladies of the Press: The Story of Women in Journalism by an Insider (New York, 1936), 441. 
platform from which to explore important social, economic, and political issues. ${ }^{13}$ Similarly, historians have noted that a number of women writers - including midwesterners Willa Cather, Edna Ferber, and Susan Glaspell - used their experiences in journalism as early fuel for their literary ambitions, although they are rarely included in the scholarship on literary realism. ${ }^{14}$ Women's entry into the public space of journalism sparked debate, although writing had long been a legitimate occupation for women because it was something they could do from their homes. ${ }^{15}$

In the midcentury Midwest, it was common for women to edit the society page or write a weekly column for their community newspapers. There is evidence to suggest that women's jobs were more multifaceted in the Midwest than on metropolitan newspapers. Ishbel Ross wrote about the early work of a few midwestern writers, such as Marguerite Martyn, who wrote features for the St. Louis Post-Dispatch, and Marguerite "Birdie" Switzer, who wrote news features, a women's column, and short fiction for the Cleveland Plain Dealer in addition to running its women's department. Eileen Wirth's book about Nebraska women journalists - the first book to chronicle the experiences of women journalists in the Midwest-demonstrates that women in rural areas and smaller cities were active contributors to their community newspapers as owner/publishers, women's page and society editors, and news reporters. ${ }^{16}$ Among Dorothy Ashby Pownall's contemporaries in Iowa were Icey Teel Harling (1902-1973), who ran the Durant News with her husband for 18 years, and Vina Roberts Thorpe (1893-1995), who published nine weekly newspapers

13. Kimberly Wilmot Voss, "Dorothy Jurney: A National Advocate for Women's Pages as They Evolved and Then Disappeared," Journalism History 36 (2010), 13-22; Jan Whitt, Women in American Journalism: A New History (Urbana and Chicago, 2008), 42-52.

14. Lutes, Front Page Girl, 123-25; Whitt, Women in American Journalism, 87106; Linda Ben-Zvi, Susan Glaspell: Her Life and Times (New York, 2005), 29-49.

15. Kimberley Mangun, "Should She, or Shouldn't She, Pursue a Career in Journalism? True Womanhood and the Debate about Women in the Newsroom," Journalism History 37 (2011), 66-79.

16. Gladys Talcott Rife, "Personal Perspectives on the 1950s: Iowa's Rural Women Newspaper Columnists," Annals of Iowa 49 (1989), 661-82; Ross, Ladies of the Press, 552-53, 555; Wirth, From the Society Page to the Front Page, 18-24, $29-54$. 
in central Iowa with her husband. ${ }^{17}$ Pownall's career was preceded by that of Susan Glaspell (1876-1948), who began writing for the Des Moines Daily News during college and worked as a reporter and columnist for that paper from 1899 to 1901 before leaving the state and becoming a celebrated novelist and playwright. ${ }^{18}$

This article is the first scholarly examination of Pownall's career, which embodied four distinct phases: (1) sob sister, (2) literary lady, (3) advice columnist, and (4) society editor. Each role represented a different response to conditions for women in the field of twentieth-century print journalism. ${ }^{19}$ Women needed to present themselves in ways that would not threaten to destabilize a historically masculine newsroom culture while internalizing enough of that culture to be successful. In some ways, Pownall's work presents her as something of a traditionalist as she fulfilled all the roles expected of a woman journalist. However, a deeper interpretation of Pownall's multifaceted career reveals her shrewd "feel for the game" as she navigated gender norms in ways that ensured her professional longevity. ${ }^{20}$

DOROTHY ASHBY, born in Superior, Wisconsin, in 1895, had been attending Lawrence College in Appleton, Wisconsin, for only one year when her father died and she was forced into the workforce. She took a job as a women's page reporter at the St. Paul (MN) Daily News in 1915 but was soon writing features for the news section. She was well regarded at the Daily News and established a reputation that went beyond the Twin Cities. After two years, she was lured south by a telegram from Bill Jarnagin, managing editor of the Des Moines Capital, a colorful afternoon newspaper in Iowa's capital with a circulation of about 50,000.

17. Guide to the Icey Lenora Teel Harling Papers, IWA, http://collguides .lib.uiowa.edu/?IWA0238; Guide to the Vina Thorpe Papers, IWA, http:// collguides.lib.uiowa.edu/?IWA0253.

18. Ben-Zvi, Susan Glaspell, 38-49.

19. Beasley and Gibbons, Taking Their Place, 31.

20. This term for a professional's way of adapting to her field comes from Pierre Bourdieu, whose social theory is useful for understanding the interplay between structure and agency in the lives of individual historical actors. Quoted in Karl Maton, "Habitus," in Pierre Bourdieu: Key Concepts, ed. Michael Grenfell (Stocksfield, UK, 2008), 49-66, 54. 
Jarnagin wanted her to provide the "woman's angle" on Camp Dodge, a U.S. Army training ground northwest of the city, as it mobilized for World War I. ${ }^{21}$ Dorothy Ashby (later Pownall) jumped at the chance to become the first woman on that beat and took the train to Des Moines in search of adventure. The St. Paul Daily News must have been sorry to lose a talented writer but wished her well. After she had gone, her former editor wrote to tell her she could return any time. "Sometime, when you get over being a militant soldier girl and want to work once more on a regular newspaper, perhaps you will find the way back to the old homestead. The latchstring will be out, anyhow, and maybe there'll be a nice, comfortable seat by the fireside!" 22

At the Capital, Pownall slipped easily into her role as a "sob sister," the term she embraced for her job, which was to report the human interest aspects in military stories and other breaking news. Being "something of an oddity," she later recalled, "was an advantage, occasionally." 23

On August 31, 1917, the Capital advertised the reporting trio it planned to send to Camp Dodge, including photos of Pownall, a male reporter, and a male photographer. As the newspaper described her role, "Miss Dorothy Ashby will handle the news from a woman's standpoint, writing that class of news known in newspaper circles as 'feature stuff.' Miss Ashby is also an experienced writer, and The Capital believes her readers will enjoy her articles." 24

The Capital might have been the first paper to send a woman journalist to the camp, but it was not alone in doing so. The Des Moines Register also hired a woman, Sue McNamara, as a wire correspondent. Pownall enjoyed a long friendship with McNamara, even after McNamara moved to Washington, D.C.

Having a "girl reporter" brought publicity. The Capital highlighted Pownall's gender in a way that was reminiscent of the

21. Dorothy Ashby Pownall, "A Girl Reporter at Camp Dodge," Palimpsest 47 (1966), 225-56. Camp Dodge was to be the largest of the 14 U.S. Army training camps in the United States and was home to the 88th Infantry Division.

22. H. B. R. Briggs to Dorothy Ashby, n.d., box 1, DAP Papers.

23. Dorothy Pownall, “Woman of the Year" speech, 4/27/1966, box 1, DAP Papers, 2.

24. Display ad, Des Moines Capital, 8/31/1917, 4. 


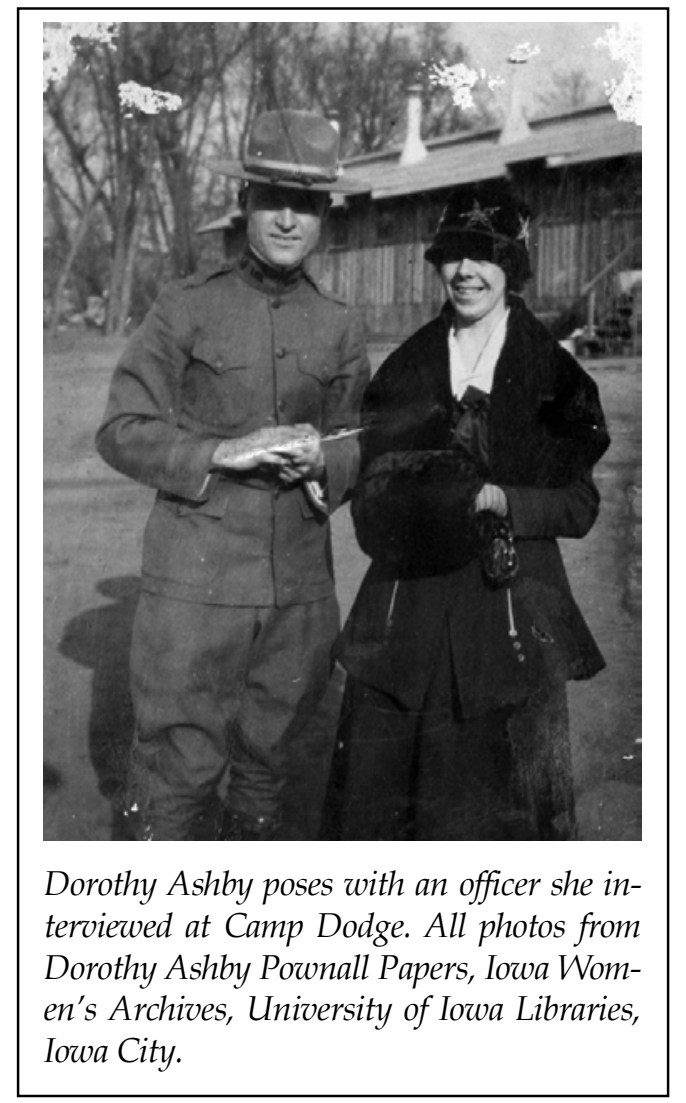

presentation large metropolitan newspapers had used to advertise their stunt reporters. By that time, both male and female reporters were getting bylines in the Capital, but, unlike its treatment of its male reporters, the newspaper also published Pownall's photo with her stories, beginning with her first front-page byline on September 5, 1917.25 In addition, editors used her name in the headlines, making her an active character in the stories and calling attention to their entertainment value: "Miss Ashby Finds Hypnotist, a Couple of Prize Fighters and 'Strong Man' at Camp Dodge"; "Miss Ashby Takes Mess With 313th Engineers - Eats Out of Mess

25. Dorothy Ashby, "Whitmer, First Man at Camp, Proud and -'It's Great,' He Says to Dorothy Ashby," Des Moines Capital, 9/5/1917, 1. 
Kit and Everything"; and "Gassed! Miss Ashby Joins Officers at Camp Dodge and Goes into the Very Midst of Poisonous Fumes." 26

There were plenty of stories for "Miss Ashby" to find at Camp Dodge, which provided temporary quarters for a total of about 150,000 soldiers before it was demobilized. In an essay reminiscing about the assignment, Pownall described her time at Camp Dodge as "some of my happiest experiences in a half century of newspaper reporting," saying she had delighted in finding the "human interest side of the sprawling, teeming training center." Every morning, she and her colleagues drove about ten miles to the camp in a Model T provided by the newspaper, their legs covered with an army blanket during the cold winter months. They enjoyed the full cooperation of the commanding officer, Major General E. H. Plummer, who told Pownall he wanted women to feel safe at the camp. Pownall never recorded any harassment from soldiers, although she acknowledged receiving patronizing treatment in the newsroom and said she had been "young and naïve and would not have recognized a leer if I saw one." 27

Pownall made daily life in the military come alive for readers. As she told it, "I snooped up and down the company streets, talking with officers and men, and watching the cross section of Middle West humanity lining up at the registration building." She attended farewell ceremonies when soldiers were deployed and memorial services when they were killed, carefully recording the reactions of mothers as their sons boarded trains or were laid to rest. She drew vivid pictures of the rank and file, capturing the diverse palette of ethnicities and backgrounds she found among the recruits (a startling contrast with the pronounced ethnocentrism of the paper's editorial page). She also wrote about the women associated with the military, including those in volunteer positions and those who had come to camp in search of loved ones. An officer who worked with Pownall at Camp Dodge wrote to a colleague that she was "the best woman reporter [he had] ever known" and had "a keen, fair and intelligent method of handling news." 28

26. Des Moines Capital, 9/18/1917, 4; ibid., 10/9/1917, 9; ibid., 1/27/1918, clipping, box 2, DAP Papers.

27. Pownall, “A Girl Reporter at Camp Dodge,” 225-26, 229-30.

28. Ibid., 235; George Walker to Maj. Butler, n.d., box 1, DAP Papers. 


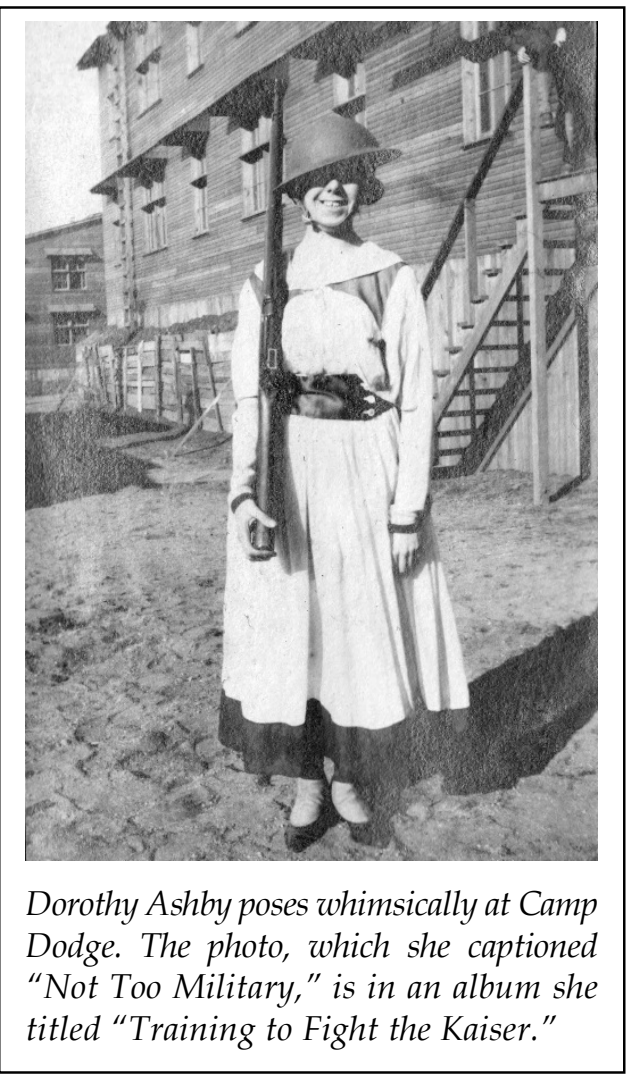

As Pownall understood it, her role as a military reporter was to "get the message to the folks at home that the servicemen were well-treated, well-fed, and happy." 29 Her dispatches were uniformly upbeat, matching the overwhelming patriotism of warrelated news while adding what she understood to be the feminine touch. Her stories were sometimes lighthearted and sometimes sorrowful, but they always provided the subjective counterpart to the straight news presented by the newspaper's male reporters.

Demonstrating her firm grasp of this dynamic, she later said, "In those good, old days, it was considered humorous to assign [girl reporters] to odd jobs like covering prize fights and wrestling matches" - so she covered them with gusto. Assigned to cover a wrestling match that featured Earl Caddock, world champion

29. Pownall, "Woman of the Year," 5. 
heavyweight, as he defended his title against a Polish wrestler at Camp Dodge, she later admitted, "I pulled out all the stops." Indeed, she breathlessly described how "the wrestlers" bodies glistened in the calcium glare" as they moved "like panthers." She shocked readers by describing how "the Pole was hurled through the ropes, once almost into the lap of a feminine watcher." 30

Writing in a conspiratorial voice, Pownall allied herself with her readers, taking them with her as she navigated the camp and interviewed officers, celebrities, and widows. She often directed her articles specifically to women, using interjections such as "you, Mrs. Housewife" or "Say, girls, you know all about those hypnotizing eyes. You must, for the movies are full of them these days." 31 Rather than position herself above events, reporting with a bird's-eye objectivity, Pownall maintained a firmly grounded position as she told stories from a visitor's perspective.

As American involvement in the war intensified during 1918, Pownall's byline appeared less frequently and more space was given to wire reports detailing troop movements and developments in Europe. Patriotic bravado gave way to the solemn realities of war, and Pownall began to look for stories outside the camp. She found the state's capital full of human drama.

Pownall developed a persona through her articles that was breezy and knowing, an example of "playing smart" in the literary style that was coming into vogue, epitomized in larger markets by writers such as Dorothy Parker. ${ }^{32}$ Her writing conveyed a sophisticated understanding of gender norms, which she appeared to acknowledge but did not fully honor. For example, when she wrote about fashion, as was expected of a woman writer, her articles carried a hint of derision. "Oh girls! Do you wear 'toothpick' heels? If you do you're not half so stylish as you think you are, besides being as uncomfortable as the law allows." 33

30. Ibid., 2; Pownall, "Girl Reporter," 252; Dorothy Ashby, "Thousands Cheer Earl Caddock, Iowa's Own Mat Idol, as He Downs the Giant Zbyszko; It's Thumbs Down for Wladek," Des Moines Capital, February 1918, clipping, box 2, DAP Papers. 31. Ashby, "Miss Ashby Finds Hypnotist," 4.

32. See Catherine Keyser, Playing Smart: New York Women Writers and Modern Magazine Culture (New Brunswick, NJ, 2011), 2-15.

33. Dorothy Ashby, "Mrs. Pennybacker Flays Bad Meals and High Heels," Des Moines Capital, 2/2/1919, box 2, DAP Papers. 
She also wrote about manners and propriety, including an article about a small scandal involving a woman passenger on a streetcar who was not wearing stockings. Even then, there were hints that she did not take social rules too seriously. Quoting the man who had called an "ossifer" on the woman, she presented the encounter more as a clash of cultures than as a true violation. "Mebbe it goes all right in the east, but we're not much for fads, here. You ain't gonna get on no car without your stockings. We can't have them wild wimmin puttin' nutty ideas in our Des Moines girls' minds." 34

It was a staple of Pownall's style to keep the subjects of her stories in perspective, even when she covered visits by Woodrow Wilson and other political dignitaries. She was also careful never to inflate her own importance. Noting the "rainbow" of hats and badges at a meeting of the League of Women Voters, Pownall insisted, "If anyone wants to know any more about the speech, he will have to ask a good reporter. There was such an intriguing hat in the second row on the platform that this sob sister missed some of the quiet eloquence." 35

It was common for Pownall to inject herself into the story in that way, as if she were an actress playing a part on stage. She also used this technique when she was not able to get a desired interview. For example, writing about a reticent soprano on tour in Des Moines, she began the story this way: "This is a drama in which a bell boy and a girl reporter are the chief participants. For color there is a grand opera star, her maid, and a breakfast tray. But the bell boy and the G.R. are the only ones who appear." 36

Pownall's writing during this period of her career was wry, astute, and often funny, but she could "sob" with the best women reporters of her day. For her first story away from Camp Dodge, she attended the first day back at school with the classmates of a little girl who had died after being struck by a car. Less than three months later, she wrote a similar story about an adult man who

34. "Horrors! Here's Girl on Street Sans Stockings" [unsigned], Des Moines Capital, n.d., [circa 1918], clipping, box 2, DAP Papers.

35. Dorothy Ashby, "New Fall Hats Seen at Davis Meeting: 'Sob Sister' Fails to Keep Her Mind on Her Job," Des Moines Capital, n.d., clipping, box 2, DAP Papers. 36. Dorothy Ashby, “'Na, na! Madame She in Bed' - and the Door Closed,” Des Moines Capital, 10/18/1917, 15. 
had been killed in a car accident, grabbing readers with this dramatic lead: "He was gone. And to the woman, lying back in the arm chair beside the little coal stove, the shock seemed almost too much to bear." In September 1919, Pownall interviewed the widow of Con McCarthy, a Des Moines detective killed while arresting a suspect, for a story splashed across the front page. She later described her writing as "melodramatic prose by a girl who had never had any trouble in her whole young life." 37 Understanding that it was her job to convey emotion, Pownall dutifully did so-but the color she added to her stories and the way she later described her work made it clear that this was a performance rather than a natural way of approaching the news.

Pownall supplemented the meager salary she received from the Capital by moonlighting as a press agent for a local stage company and as a stringer for the Davenport Democrat, covering the state capital for the eastern Iowa newspaper. Her staff position at the Capital paid off in other ways, however. She met her husband, Fred Pownall, at the newspaper, where he served as telegraph editor, city editor, and eventually executive editor until the Des Moines Register and Tribune absorbed the Capital in 1927.38 That year, Fred Pownall was offered a job as director of publications and journalism professor at the University of Iowa (then called the State University of Iowa). The next phase of Dorothy Pownall's career would be a more fluid one as she created a life of letters reminiscent of women writers in the nineteenth century. She became a literary lady, writing poetry and nonfiction for national periodicals while running her household and caring for three children.

POWNALL displayed a temperate understanding of gender roles even as she advocated for women in public capacities. Speaking years later about the suffragists she had once covered, she emphasized, "These were not militant women, but intelligent

37. Dorothy Ashby, "Sorrow Hovers over Nollen School Today for Little Hortense Will and Her Happy Smile Have Gone Forever," Des Moines Capital, 10/16/ 1917, 1; Dorothy Ashby, "Husband of Mrs. Thomas Dies from Injuries Received in Street Car Wreck the Day Their Paroled Son Comes Back Home from Prison," Des Moines Capital, 1/12/1918, 1; Pownall, "Woman of the Year," 4.

38. Phyllis Fleming, "Their World Seldom Dull: Coffee Pot Always on at Dorothy and Fred Pownalls," Cedar Rapids Gazette, 10/29/1961, clipping, box 1, DAP Papers. 
students of local, state and national affairs," thus bestowing her approval on their decorous, moderate brand of advocacy. ${ }^{39}$ As the founding president of the Des Moines Women's Press Club when it was established in 1919, Pownall asserted women's right to organize and engage in public roles - as long as they did so within the bounds of acceptability. "In Iowa," she wrote, "there are many women [engaged] in newspaper work. There are city editors; woman's editors; society editors, reporters, and women who conduct social departments." The subject of that article, the owner and publisher of a newspaper in northwestern Iowa, insisted that women were well prepared for such work because "it's the woman reader who can make or break a paper." 40

Pownall used her contacts with prominent women to feed the freelance phase of her career, writing profiles of women such as Agnes Samuelson, state superintendent of public schools, and Mary Watts, a promoter of the "better babies" movement. In 1922 she wrote a uniformly positive article about the formation of a Department of Women's Affairs within the Des Moines Chamber of Commerce, which she called "the first and only one of its kind in the country." The group had charged itself with improving the conditions and productivity of employed women in the city by advocating for better housing and educating younger women about how to be successful in business. ${ }^{41}$

Pownall wrote extensively about women, children, and parenting, reflecting her belief, according to a reporter who interviewed her, that "writing and homemaking are an excellent combination." 42 Pownall encouraged other women to use the same

39. Dorothy Ashby Pownall, "I Was There," speech given at the Iowa convention of the League of Women Voters, 5/8/1969, box 1, DAP Papers.

40. Dorothy Ashby, "Can a Woman Successfully Edit and Publish a Weekly Newspaper? 'Sure,' Declares Mrs. Anna Donovan of Emmetsburg Tribune," Des Moines Capital, n.d., clipping, box 2, DAP Papers.

41. Dorothy Ashby Pownall, "Fitter Families: The Idea of an Iowa Woman," The Iowa Magazine, 3/13/1923, box 2, DAP Papers; Dorothy Ashby Pownall, "A Club for Women of Big Business," Woman's Weekly: The Magazine of Service, 3/4/1922, box 2, DAP Papers, 1.

42. Johanna Nelson, "From 'Sob Sister' to Magazine Writer-Mrs. Fred M. Pownall Has Three-Sided Career; Knowing Success in Journalism, She Takes Unbounded Interest in Young Writers," Iowa City Press-Citizen, 2/26/1939, clipping, box 1, DAP Papers. 
strategy, advising aspiring writers, "There are so many incidents in our daily lives that others like to read about. Telling how you solved domestic problems, taught good manners to your children or helped organize your neighborhood in a project helpful to your community" could provide a creative outlet and a reasonable income even if it did not sound glamorous. ${ }^{43}$

After writing every morning, Pownall devoted the rest of her day to her husband and three daughters. She took advantage of her access to local researchers at the University of Iowa to write about studies related to child development. Yet even on that subject, she dropped hints that she did not take the hype about scientific parenthood too seriously. For example, she wrote a humorous poem titled "Preschool Soliloquy," which was published in the Saturday Evening Post. The poem - written from the point of view of a child (a "prescholar") - seems to make light of convoluted psychological explanations for what might be considered normal childhood behavior. Throughout the poem, a child narrator mocks his parents' earnest attempts to ensure that he is properly stimulated and prepared for high achievement while subtly suggesting a connection between their progressive parenting and his own propensity for poor behavior. He holds himself up as the "Perfect Problem Child," a complex specimen studied at conferences, yet punctuates his soliloquy with a brief outburst that readers would recognize as a typical childish tantrum. ${ }^{44}$

Pownall also poked sly fun at a strain of provincial culture that might have cast her and Fred as "Ma and $\mathrm{Pa}$," with "Ma" judged solely on the basis of her capability in the kitchen. One of her poems, written from a wife's perspective, ended with this declaration of gratitude: "I love him most, however, comma/ Because he never calls me "mamma.'" 45 This sort of wry humor suggests that while Pownall might have presented herself as a domestic expert, dispensing common sense with the authority of a midwestern homemaker, there was more to her worldview.

43. Pownall, "Woman of the Year," 11. For examples of Iowa women who took up this task, see Rife, "Personal Perspectives."

44. Dorothy Pownall, "Preschool Soliloquy," Saturday Evening Post, 11/5/1932, box 2, DAP Papers.

45. Dorothy Pownall, "Lines to the Papa," Saturday Evening Post, 10/1/1932, box 2, DAP Papers. 


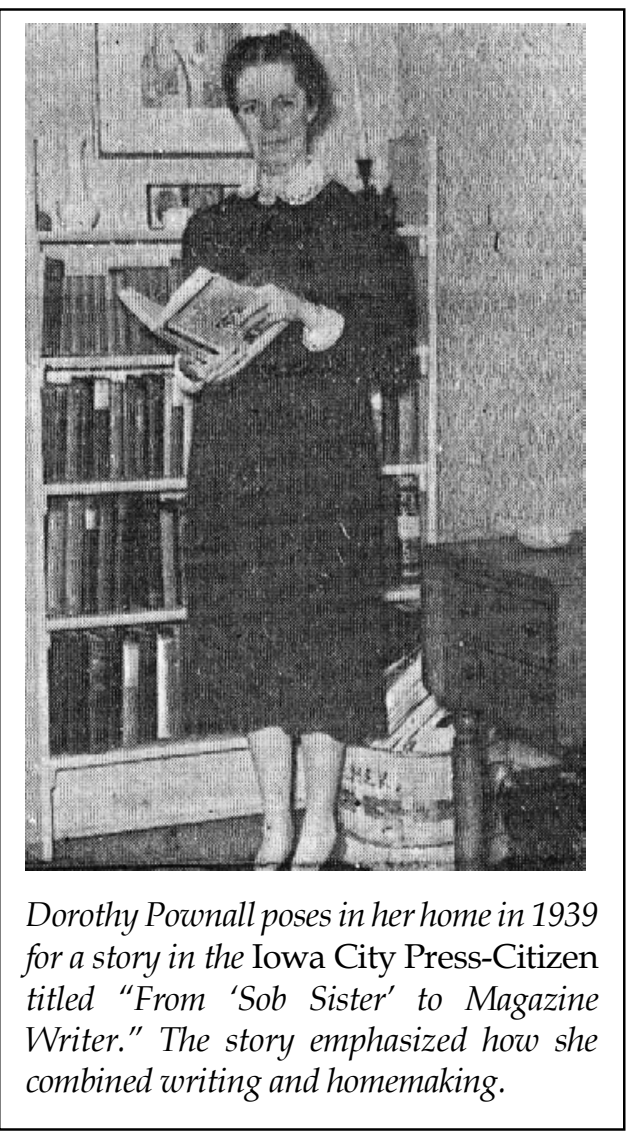

Pownall's witty poems and limericks - featured in Photoplay Magazine and even read by actors as part of Fred Stone's traveling show - appealed to social critics and progressive thinkers. ${ }^{46}$ She took her place among the community's intelligentsia as a founding member of the Society for the Prevention of Cruelty to Speakers (SPCS), a social club of 16 University of Iowa faculty, students, and community members who invited literary speakers, such as Gertrude Stein, to Iowa City with the promise of a good time. The freewheeling SPCS also included Frank Luther Mott, a respected journalism historian and writer, and painter Grant Wood, already famous for American Gothic. Notably, the group

46. Charles “C. B.” Dillingham to Dorothy Pownall, 1/22/1923, box 1, DAP Papers. 
did not count Fred Pownall as a member, which suggests that Dorothy had established an intellectual identity beyond that of a typical faculty wife. In 1935 she was invited to speak about magazine writing at the Iowa Writers' Workshop, which was gaining respect among literary enthusiasts. ${ }^{47}$

Pownall's poetry adopted a more solemn and religious tone after the tragic death of her six-year-old daughter, Carol, who was hit by a car outside the family's home in June 1933. ${ }^{48}$ A series of poems - "Winter Again," "Six Years Old," "Spring Always Comes," and "Such a Little Child" - on that devastating loss published in Ladies' Home Journal generated mail from people grateful to her for giving voice to a mother's grief. Subsequent verses Pownall wrote for Ladies' Home Journal and Good Housekeeping emphasized God and faith, although it is difficult to say whether this represented a more pronounced religiosity in Pownall's outlook or a response to demand from mass-market magazines in search of conventional content. Perhaps more revealing of Pownall's approach to personal tragedy is that, aside from these four poems, no mention of Carol's death ever appeared in Pownall's writing or in profiles written about her, even those that mentioned her other two daughters, Eleanor and Dorothy.

POWNALL might have kept her own troubles out of public view, but she readily aired the private lives of anonymous others in an advice column she started in 1929. Writing as Mary Manners, Pownall received enough mail to publish a daily column for ten years in the Cedar Rapids Gazette, the state's second-largest newspaper. Although Pownall later would minimize her role as "a sort of poor folks' Dear Abby," in reality she published letters that exposed the inner workings of relationships and provided a forum for passionate lifestyle debates. Topics included monogamy, marriage, drinking, dating, friendships, and even the mythology that surrounded rural life. ("When someone tells you what a swell place a farm is, turn a deaf ear and stick to your city job,"

47. Frank Luther Mott, "The Society for the Prevention of Cruelty to Speakers," Palimpsest 43 (1962), 113-32; Frank Luther Mott to Dorothy Pownall, 4/9/1962, box 1, DAP Papers.

48. “A Newspaper Family's Sad Bereavement," Mason City Globe-Gazette, 6/23/ 1933. 
one writer stated. Another boldly asserted, "As for the farmers, I have yet to meet one who does not crave pity, while city folks keep their chins up." ${ }^{49}$ )

Under the cover of anonymity, readers expressed all manner of forceful opinions and divulged shocking secrets. One writer made it known that she and her husband drank heartily with their friends, launching a Prohibition-era debate over the merits and demerits of alcohol. (Mary Manners came down on the side of abstinence.) Another time, Pownall published a letter from a married woman who was secretly in love with another man but could not bring herself to tell him. That man recognized himself in the letter and professed his mutual adoration, resulting in the woman's divorce and a letter updating Mary Manners on their subsequent marriage. After that episode, Pownall's husband told her, "It's lucky you didn't land in jail for this." 50

A similar pair of letters to Pownall came from a married woman who was distraught over a six-year affair she had been having with another man, which she could not bring herself to end. She wrote of having visited three male experts for help: a "rather famous psychoanalyst" at the University of Iowa, her minister, and the family physician. The psychologist and physician responded by making sexual advances toward her, and the minister betrayed her confidence, leaving her disillusioned and feeling so hopeless that she had considered suicide. In a subsequent letter, she wrote of consulting a divorce attorney who suggested that she stay married and continue the affair. "Isn't it strange that the four men who are all highly educated, and trained, would take the same general view of something which has got me completely haywire?" she wrote to Pownall, who had responded in print by asking "Tabloid," as the woman signed her letters, for a self-addressed envelope so that she might reply to her personally. The woman was not willing to risk outing herself by giving Mary Manners a mailing address. One reason she was so distressed

49. Pownall, "Woman of the Year," 9; Mary Manners [Dorothy Pownall], " 'Irresistible' Tom Suffers Deflation from Girl Who Is Unimpressed by His Tricks," Cedar Rapids Gazette, 3/29/1936, 4; Mary Manners [Dorothy Pownall], "Easter Is Reminder of New Hopes, Beauty in Nature, and Smallness of Personal Woes," Cedar Rapids Gazette, 4/12/1939, 8.

50. Fleming, "Their World Seldom Dull." 
was that she had given birth to a child who, unbeknownst to her husband, was her lover's biological son. Pownall responded with compassion to such readers, seeming to understand the cruel trappings of a proper middle-class life, especially for women. Her advice might have been trite, but it was not judgmental. ${ }^{51}$

In the advice she delivered about romance and friendship Pownall emphasized morality, modesty, understanding, and common sense-although she suspected that a number of letters came from teenagers and "young people having some fun with me." 52 It is significant that she gave space to all perspectives, even those considered controversial, and offered comfort to women who had been betrayed or otherwise mistreated by the men in their lives. Simply by creating a forum for the discussion of domestic issues in a newspaper, she blurred the line between what was considered public and what was kept private. In a tactic similar to that adopted by women's page editors, she used the editorial license granted to a seemingly trivial column to carve out a space in the public sphere for voices and concerns that otherwise might not have been heard. Men as well as women read the feature, which the Gazette frequently plugged on the front page. Pownall continued "Mary Manners" until 1939, when she ended it for reasons that are not clear from her records.

SEVERAL YEARS LATER, the editor of the Iowa City PressCitizen approached Pownall with an offer-"something absolutely new" - to become the newspaper's society editor. Her husband told her she should take the job because "she was on the phone all the time anyway." She said it was a positive experience because of the autonomous nature of the position: "I did it all myself." 53

Society editor was a far more traditional position for newspaperwomen than any of the prior work Pownall had done. Society news was the section of a women's department that chronicled the social lives of residents who enjoyed enough status to

51. Letters to Mary Manners [Dorothy Pownall], signed “Tabloid," n.d., box 2, DAP Papers.

52. Pownall, "Woman of the Year," 9.

53. Ibid., 10; Fleming, "Their World Seldom Dull." 
see their names in print. Calls came in regularly from women with news to share of club meetings, fundraisers, weddings, and socializing. It was the editor's job to decide which items to publish, which ones deserved a full story, and how the page should be laid out. Charlotte Curtis, the legendary New York Times society editor (and native of the Midwest) known for insisting that not all brides were beautiful, described the job this way: "Reporting a society story or a woman's news story, or anything, the techniques of reporting are the same regardless of what you do. ... Something has happened - a wedding has happened, a charity ball has happened, a murder has happened. . . . You answer all the who, what, why, when and where and how and so on, but what you're doing is telling the world it happened. And if you can, you try and tell them what it means, if anything." 54

In recent years, historians have begun revisiting the women's sections of newspapers, finding them to be an important site of public discourse that has been neglected in the scholarly literature. For example, Curtis used her degree in sociology to give a sharper edge to the New York Times society page, just as other women's page editors used their food sections to explore cooking as both an art and a science. ${ }^{55}$ That sort of analysis was absent from Pownall's society page, however, as was her characteristic humor. There is little evidence in her records to indicate her method of managing this section, apart from her claim that she put it out entirely on her own. Under her leadership, the page, titled "Society - Clubs," handled traditional women's content, including news of weddings, social gatherings, and club work in addition to short, standing features on fashion, cooking, and a daily item provided by the Child Welfare Service. The page was clean, the copy was crisp, and the content was straightforward. The formulaic nature of the page was more conservative than one might have expected, given Pownall's eclectic body of work. Yet the section earned numerous awards from the Iowa Press Women and the National Federation of Press Women during her tenure, including first place for best women's department at a U.S. daily

54. Quoted in Marilyn Greenwald, A Woman of the Times: Journalism, Feminism, and the Career of Charlotte Curtis (Athens, OH, 1999), 75.

55. See Kimberly Wilmot Voss, The Food Section: Newspaper Women and the Culinary Community (Lanham, MD, 2014). 


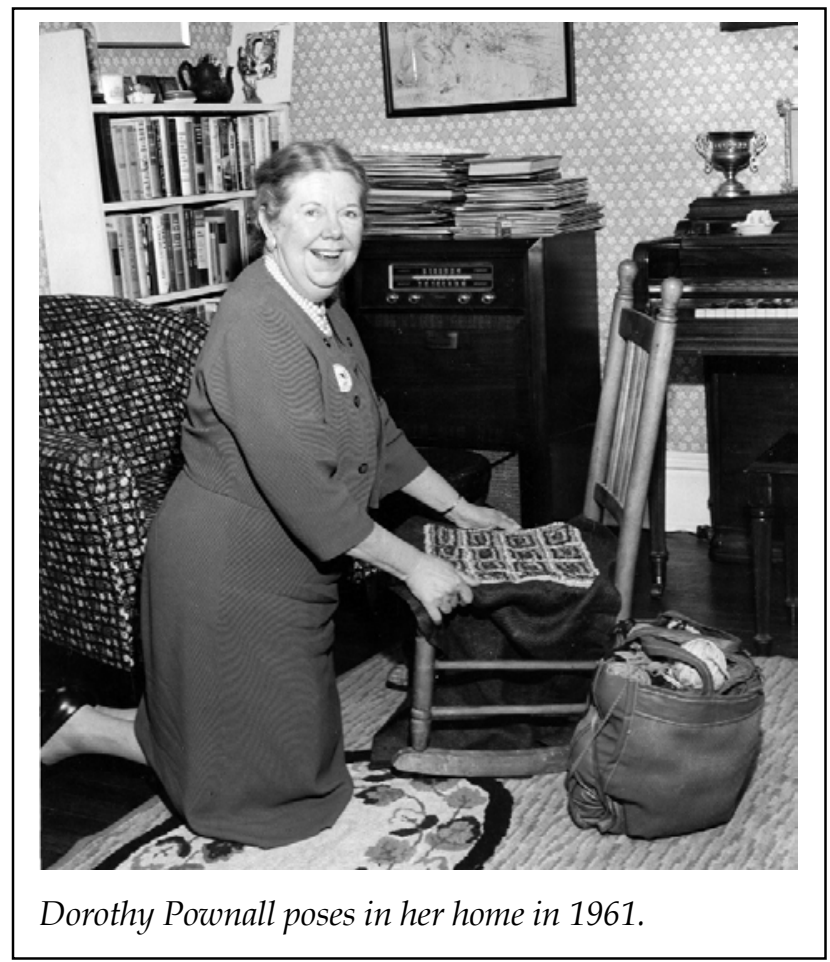

newspaper with a circulation of more than 2,500. Pownall also wrote feature articles for the general news section of the paper and won several awards for those, including a Golden Grand Merit award and one for "versatility" as a journalist. ${ }^{56}$

The latter award certainly fit a woman who, as a journalist, had worn as many hats as she had seen at her first suffrage meeting. After retiring from the Iowa City Press-Citizen in 1955, Pownall continued to write freelance articles, including an award-winning historical essay in the Palimpsest about covering Camp Dodge. ${ }^{57}$ She and her husband also continued to entertain and enjoy the success of their daughters, one of whom worked for magazines as a freelance artist and one of whom worked in the psychology department at Miami University of Ohio. Throughout their lives,

56. "Press-Citizen Society Editor Receives 3 Press Awards," Iowa City PressCitizen, 4/20/1953, box 1, DAP Papers.

57. Pownall, "A Girl Reporter at Camp Dodge." 
Dorothy and Fred Pownall provided generous counsel to young people interested in journalism; there is still a scholarship in each of their names at the University of Iowa School of Journalism and Mass Communication.

DOROTHY ASHBY POWNALL'S storied career might have faded from public memory, but there is much to learn from it. The fluidity with which Pownall moved through the gendered roles she played demonstrates, to a significant degree, her feel for the game. Faced with a field that was challenging for women, Pownall found ways to navigate that field successfully while demonstrating that gender could be used to one's advantage. By trading on her femininity as a sob sister, Pownall earned the approval of editors, who saw the market value in playing up her gender with a byline and photo. By tailoring her freelance work to fit her life as a homemaker and by leveraging her contacts as a faculty wife, Pownall found national outlets for her journalism and poetry. By posing as the prim but compassionate Mary Manners, Pownall gave space to scintillating human drama and created a forum for public discussion of private issues primarily of interest to women. By capitalizing on her social status and experience, Pownall was able to retire as an award-winning society editor. Each phase of her career was skillfully molded to fit a gendered archetype, resulting in a set of practices that enabled her to continue to find work. If one thinks of such practices as "embodied history," one recognizes in Pownall's career the grooves of many years of gendered patterns, performances, and traditions. ${ }^{58}$

58. Pierre Bourdieu, The Logic of Practice, trans. Richard Nice (Cambridge, 1990), 56. 